\title{
PENGUATAN MAHKAMAH KONSTITUSI REPUBLIK INDONESIA MELALUI Constitutional Complaint
}

\author{
Andryan dan Eka NAM Sihombing \\ Fakultas Hukum Universitas Muhammadiyah Sumatera Utara \\ Jalan Muchtar Basri No. 3 Medan dan \\ Kanwil Kementerian Hukum dan HAM Sumatera Utara \\ Jalan Putri Hijau No. 4 Medan \\ email: andryan@umsu.ac.id
}

\section{A. PENDAHULUAN}

Reformasi konstitusi dengan ditandai amandemen Undang-Undang Dasar Negara Republik Indonesia Tahun 1945 pada periode 1999-2002, membawa implikasi terhadap struktur dalam sistem ketatanegaraan Republik Indonesia. Perubahan yang sangat mendasar tersebut juga melahirkan banyak kelembagaankelembagaan negara baru, yang diharapkan akan mampu menopang dalam aspek-aspek kehidupan berbangsa dan bernegara. Salah satu lembaga negara yang lahir dari rahim reformasi adalah Mahkamah Konstitusi (MK), dimana lembaga negara tersebut mempunyai kedudukan sebagai pengadilan konstitusi.

Pemikiran mengenai pentingnya suatu pengadilan konstitusi telah muncul dalam sejarah ketatanegaraan Indonesia sebelum kemerdekaan. Pada saat pembahasan rancangan UUD di Badan Penyelidik Usaha-usaha Persiapan Kemerdekaan Indonesia (BPUPKI), anggota BPUPKI Prof. Muhammad Yamin telah mengemukakan pendapat bahwa Mahkamah Agung (MA) perlu diberi kewenangan untuk membanding Undang-Undang. Namun ide ini ditolak oleh Prof. Soepomo berdasarkan dua alasan, pertama, UUD yang sedang disusun pada saat itu (yang kemudian menjadi UUD 1945) tidak menganut paham trias politika. Kedua, pada saat itu jumlah sarjana hukum kita belum banyak dan belum memiliki pengalaman mengenai hal ini.

Pada saat pembahasan perubahan UUD 1945 dalam era reformasi, pendapat mengenai pentingnya suatu Mahkamah Konstitusi muncul kembali. Perubahan UUD 1945 yang terjadi dalam era reformasi telah menyebabkan Majelis Permusyawaratan Rakyat (MPR), tidak lagi berkedudukan sebagai lembaga tertinggi negara dan supremasi telah beralih dari supremasi MPR kepada supremasi konstitusi. ${ }^{1}$ Akibat perubahan yang mendasar itu, maka perlu disediakan sebuah mekanisme institusional dan konstitusional serta hadirnya lembaga negara yang mengatasi kemungkinan sengketa antarlembaga negara yang kini telah menjadi sederajat serta saling mengimbangi dan saling mengendalikan (checks and balances). Seiring dengan itu muncul desakan agar tradisi pengujian peraturan perundang-undangan perlu diperkuat tidak hanya terbatas pada peraturan di bawah undang-undang (UU) melainkan juga atas UU terhadap UUD. Kewenangan melakukan pengujian UU terhadap UUD itu diberikan kepada sebuah mahkamah tersendiri di luar Mahkamah Agung. Atas dasar pemikiran itu, adanya Mahkamah Konstitusi yang berdiri sendiri di samping Mahkamah Agung menjadi sebuah keniscayaan.

Dalam perkembangannya, ide pembentukan Mahkamah Konstitusi mendapat respon positif dan menjadi salah satu materi perubahan UUD yang diputuskan oleh MPR. Setelah melalui proses pembahasan yang mendalam, cermat, dan demokratis, akhirnya ide Mahkamah Konstitusi menjadi kenyataan dengan disahkannya Pasal 24 ayat (2) dan Pasal 24C UUD 1945 yang menjadi bagian Perubahan Ketiga UUD 1945 pada Sidang Tahunan MPR 2001 tanggal 9 November 2001. Dengan disahkannya dua pasal tersebut, maka Indonesia menjadi negara ke78 yang membentuk MK dan menjadi negara pertama pada abad ke-21 yang membentuk lembaga kekuasaan kehakiman tersebut. Pasal 24 ayat (2) UUD 1945 menyatakan:

"Kekuasaan kehakiman dilakukan oleh sebuah Mahkamah Agung dan badan peradilan yang berada di bawahnya dalam lingkungan peradilan umum, lingkungan peradilan agama, lingkungan peradilan militer, lingkungan

1 Lihat Pasal 1 ayat (2) UUD 1945, bahwa "Kedaulatan berada di tangan rakyat dan dilaksanakan menurut Undang-Undang Dasar". 
peradilan tata usaha negara, dan oleh sebuah Mahkamah Konstitusi”.

Berdasarkan ketentuan tersebut, Mahkamah Konstitusi adalah salah satu pelaku kekuasaan kehakiman selain Mahkamah Agung. Dengan demikian, Mahkamah Konstitusi adalah suatu lembaga peradilan, sebagai cabang kekuasaan yudikatif, yang mengadili perkaraperkara tertentu yang menjadi kewenangannya berdasarkan ketentuan UUD 1945. Sesuai ketentuan Pasal 24C ayat (1) UUD 1945, Mahkamah Konstitusi mempunyai wewenang (a) Menguji undang-undang terhadap UUD; (b) Memutus sengketa kewenangan lembaga negara yang kewenangannya diberikan oleh UndangUndang Dasar; (c) Memutus pembubaran partai politik; (d) Memutus perselisihan tentang hasil pemilihan umum; dan (e) Memutus pendapat DPR bahwa Presiden dan/atau Wapres telah melakukan pelanggaran hukum berupa pengkhianatan terhadap negara, korupsi, penyuapan, tindak pidana berat lainnya, atau perbuatan tercela dan/atau pendapat bahwa Presiden dan/atau Wakil Presiden tidak lagi memenuhi syarat sebagai Presiden dan/ atau Wakil Presiden.

Menjadi persoalan ketika Mahkamah Konstitusi telah berumur lebih dari satu dekade, bahwa terdapat banyak hak-hak konstitusional warga negara yang terabaikan oleh para penyelenggara negara. Padahal, dibentuknya Mahkamah Konstitsui sejak tahun 2003, tidak lain untuk melindungi hak-hak konstitusional yang dilanggar oleh negara, sehingga keberadaan Mahkamah Konstitusi di Indonesia tidak lain adalah sebagai pengawal UUD 1945 (the quardian of the constitution) dan penafsir UUD 1945 (the interpreter of the constitution).

Pelanggaran hak konstitusional warga negara dalam ketentuan peraturan perundangundangan dapat diselesaikan melalui mekanisme judicial review. Untuk tindakan atau keputusan penyelenggara negara yang melanggar hak konstitusional digunakan mekanisme peradilan biasa, terutama terhadap pelanggaran yang terjadi karena penyalahgunaan wewenang dan penafsiran yang keliru, misalnya melalui peradilan pidana, perdata, maupun tata usaha negara. Hal yang menjadi pertanyaan, bagaimana ketentuan penyelesaian pelanggaran terhadap hak konstitusional warga negara yang tidak diatur dalam Undang-Undang, pada umumnya dikenal dengan mekanisme Constitutional Complaint?

\section{B. Pembahasan}

\section{B.1. Supremasi Negara Hukum}

Negara hukum diistilahkan dengan nama rechstaats atau the rule of law. Di Indonesia, pendirian negara sejak semula telah di citacitakan oleh the founding father sebagai suatu negara hukum. Dalam rangka perubahan ketiga UUD 1945 Pasal 1 ayat (3) ditegaskan bahwa "Negara Indonesa adalah Negara Hukum". ${ }^{2}$ Meskipun secara eksplisit telah tertuang dalam konstitusi sebagai negara yang berdasarkan atas hukum, namun cetak biru dan desain makro penjabaran ide negara hukum belum secara tegas dirumuskan secara komprehensif.

Ide negara hukum sesungguhnya telah lama dikembangkan oleh para filsuf dari zaman Yunani Kuno, Plato, dalam bukunya "the Statesman" dan "the Law", menyatakan bahwa negara hukum merupakan bentuk paling baik kedua (the second best) guna mencegah kemerosotan kekuasaan seseorang adalah pemerintahan oleh hukum. Konsep negara hukum modern di Eropa Kontinental dikembangkan dengan menggunakan istilah Jerman yaitu rechtsstaat' antara lain oleh Immanuel Kant, Paul Laband, Julius Stahl, Fichte, dan lain-lain. Sedangkan tradisi Anglo Amerika, konsep negara hukum dikembangkan dengan sebutan "the rule of law" yang dipelopori oleh A.V.Dicey. ${ }^{3}$

Dalam hal itu, ide negara hukum, selain terkait dengan konsep "rechtsstaat" dan "the rule of law", juga terkait dengan konsep "nomocracy" yang berasal dari perkataan "nomos" dan "cratos". Perkataan nomokrasi itu dapat dibandingkan dengan "demos" dan "cratos" atau "kratien" dalam demokrasi. Nomos berarti norma, sedangkan cratos adalah kekuasaan. ${ }^{4}$ Menurut Julius Stahl, konsep Negara Hukum yang disebutkannya dengan istilah "rechtsstaat" itu mencakup empat elemen penting, yaitu: ${ }^{5}$

1. Perlindungan hak asasi manusia;

2. Pembagian kekuasaan;

3. Pemerintahan berdasarkan undang-undang;

4. Peradilan tata usaha negara.

2 Konsepsi Negara Hukum, sebelumnya hanya tercantum dalam Penjelasan UUD 1945, yang menyatakan bahwa Negara Indonesia berdasar atas hukum (rechtsstaat), tidak berdasarkan kekuasaan belaka (machtsstaat).

3 Jimly Asshiddiqie, Konstitusi dan Konstitusionalisme Indonesia, Edisi Revisi, Konstitusi Press, Jakarta, 2005, hlm.152

4 Jimly Asshiddiqie, Menuju Negara Hukum Yang Demokratis,PT.Bhuana Ilmu Populer, Jakarta, 2009, hlm.189

5 Ibid. hlm. 199 
Sedangkan A.V.Dicey, menguraikan adanya tiga ciri penting dalam setiap Negara Hukum yang disebutkannya dengan istilah "The rule of law", "The rule of law", yaitu: ${ }^{6}$

1. Supremacy of Law;

2. Equality Before The Law;

3. Due Process of Law.

Keempat prinsip "rechtsstaat" yang dikembangkan oleh Julius Stahl dapat digabungkan dengan ketiga prinsip "Rule of Law" yang dikembamgkan oleh A.V.Dicey untuk mencapai ciri-ciri Negara Hukum modern. Selain daripada itu, oleh "The International Commission of Jurist", prinsip-prinsip Negara Hukum juga meliputi, (1) negara harus tunduk pada hukum; (2) pemerintah menghormati hak-hak individu dan (3) peradilan bebas dan tidak memihak.

Profesor Utrecht membedakan antara Negara hukum formil atau Negara hukum klasik, dan negara hukum materiel atau Negara hukum modern ${ }^{7}$. Negara hukum formil menyangkut pengertian hukum yang bersifat formil dan sempit, yaitu dalam arti peraturan perundangundangan tertulis. Sedangkan yang kedua, yaitu Negara Hukum Materiel yang lebih mutakhir mencakup pula pengertian keadilan di dalamnya. Karena itu, Wolfgang Friedman dalam bukunya 'Law in a Changing Society' membedakan antara 'rule of law' dalam arti formil yaitu dalam arti 'organized public power', dan 'rule of law' dalam arti materiel yaitu 'the rule of just law'.

Pembedaan ini dimaksudkan untuk menegaskan bahwa dalam konsepsi negara hukum itu, keadilan tidak serta-merta akan terwujud secara substantif, terutama karena pengertian orang mengenai hukum itu sendiri dapat dipengaruhi oleh aliran pengertian hukum formil dan dapat pula dipengaruhi oleh aliran pikiran hukum materiel. Jika hukum dipahami secara kaku dan sempit dalam arti peraturan perundang-undangan semata, niscaya pengertian negara hukum yang dikembangkan juga bersifat sempit dan terbatas serta belum tentu menjamin keadilan substantive. Karena itu, di samping istilah 'the rule of law' oleh Friedman juga dikembangkan istilah 'the rule of just law' untuk memastikan bahwa dalam pengertian kita tentang 'the rule of law' tercakup pengertian keadilan yang lebih esensiel daripada sekedar memfungsikan peraturan perundang- undangan dalam arti sempit. Kalaupun istilah yang digunakan tetap 'the rule of law', pengertian yang bersifat luas itulah yang diharapkan dicakup dalam istilah 'the rule of law' yang digunakan untuk menyebut konsepsi Negara hukum di zaman sekarang. ${ }^{8}$

Dengan adanyabeberapa prinsip dalam sebuah Negara Hukum yang dikemukakan oleh Julius Stahl dan A.V.Dicey, maka dapat dirumuskan salah satu prinsip pokok Negara Hukum sebagai pilar-pilar utama yang menyangga berdirinya dan tegaknya suatu negara modern yang disebut sebagai Negara Hukum (The rule of law ataupun rechtsstaat), adalah perlindungan hak-hak warga negara.

Perlindungan terhadap hak asasi manusia dimasyarakatkan secara luas dalam rangka mempromosikan penghormatan dan perlindungan terhadap hak-hak asasi manusia sebagai ciri yang penting suatu negara hukum yang demokratis. Setiap manusia sejak kelahirannya menyandang hak-hak dan kewajiban-kewajiban yang bersifat bebas dan asasi. Terbentuknya negara dan demikian pula penyelenggaraan kekuasaan suatu negara tidak boleh mengurangi arti atau makna kebebasan dan hak-hak asasi kemanusiaan itu. Karena itu, adanya perlindungan dan penghormatan terhadap hak-hak asasi manusi itu merupakan pilar yang sangat penting dan setiap negara yang disebut sebagai negara hukum. jika dalam suatu negara, hak asasi manusia terabaikan atau dilanggar dengan sengaja dan penderitaan yang ditimbulkannya tidak dapat di atasi secara adil, maka negara yang bersangkutan tidak dapat disebut sebagai Negara Hukum dalam arti yang sesungguhnya. ${ }^{9}$

Muhammad Yamin, menyatakan bahwa manusia dilahirkan untuk kemerdekaan yang sebenar-benarnya dan sepenuh-penuhnya. Yamin menganggap bahwa rantai yang membelenggu manusia perlu diputus sehinga hilanglah berbedaan dan lahirlah persamaan hak. Dengan demikian, HAM merupakan konsepsi ideal yang harus dirumuskan dalam UUD 1945. Tujuan pembentukan Republik Indonesia sebagai negara yang dicita-citakan sebagai sebuah negara hukum dan suatu negara kebangsaan yakni mewujudkan empat istilah konstitusi: kebahagiaan, kesejahteraan, perdamaian dan kemerdekaan. ${ }^{10}$

6 Ibid.

7 Utrecht, Pengantar Hukum Administrasi Negara Indonesia, Ichtiar, Jakarta, 1962, hlm. 9

8 Ibid

9 Jimly Asshiddiqie, Negara Hukum Indonesia, Makalah, dalam rangka Pelantikan Dewan Pimpinan Pusat Ikatan Alumni Universitas Jayabaya, di Jakarta, 2010

10 Jurnal Hukum Jentera, Komisi Negara, PSHK, Edisi 12-Tahun III, Jakarta, 2006, hlm.134 


\section{B.2. Konsepsi Constitutional Complaint}

Setiap negara yang memiliki lembaga peradilan bernama Mahkamah Konstitusi (MK), memiliki fungsi sebagai pengawal konstitusi (the guardian of constitution), penegak demokrasi, penjaga hak asasi manusia, bahkan penafsir tunggal (sole interpreter) konstitusi. Contohnya di Korea Selatan, lambang dan kredonya adalah "the protector" atau sang pelindung Konstitusi. ${ }^{11}$

Konsep mengenai wewenang menguji untuk menjaga kesucian konstitusi oleh lembaga yudisial ini dapat melihat beberapa putusan yang dikeluarkan oleh Mahkamah Agung di Amerika Serikat. Di dalam memberikan putusan, MA dapat berdasarkan pada peraturan yang dibuat oleh Kongres maupun pada doktrin. Sebagian besar kasus yang ditangani MA merupakan hasil interpretasi hukum dalam menentukan apakah suatu peraturan atau pejabat berjalan sesuai dengan konstitusi atau tidak. Wewenang MA ini tidak disebutkan secara khusus dalam konstitusi AS, akan tetapi didasarkan pada doktrin yang disimpulkan oleh MA berdasarkan naskah konstitusi dan telah dinyatakan secara gamblang dalam kasus penting yaitu Marbury vs. Madison tahun 1803. Dalam putusannya MA dengan hakim Marshall menyatakan bahwa “... tindakan legislatif yang bertentangan dengan Konstitusi bukanlah Hukum...", dan lebih lanjut menambahkan bahwa "adalah wewenang dan tugas dan wewenang dari lembaga peradilan untuk menyatakan apakah hukum itu". Atas dasar inilah, maka MA mempunyai wewenang untuk melakukan pengujian (yudicial review) terhadap undang-undang yang dianggap bertentangan dengan konstitusi AS. ${ }^{12}$

Tradisi AS inilah yang kemudian menjadi tonggak bagi lahirnya ajaran supremasi konstitusional dalam pengujian peraturan perundang-undangan. Menurut Smith Baily (Inggris), bahwa yudicial review didirikan atas dasar doktrin Ultra Vires (ultra vires doctrin) yang digunakan dalam sistem hukum di Inggris. Berdasarkan doktrin tersebut kekuasan yudikatif diberikan hak dan kewenangan untuk ${ }^{13}$ :

a. mengawasi batas kewenangan pemerintah dalam mengeluarkan peraturan perundangundangan (statutory authority) sesuai dengan batas yurisdiksi atau kawasan kekuasaannya. b. kekuasaan yudikatif diberikan hak, fungsi dan kewenangan untuk melakukan pengawasan terhadap penguasa pusat maupun daerah dan local untuk tidak melakukan penyalahgunaan kekuasaan (abuse of power) melampaui batas-batas yurisdiksinya.

c. Apa-apa yang tidak didelegasikan undangundang kepada penguasa, atau membuat peraturan perundang-undangan yang jauh lebih luas dari apa yang telah didelegasikan, harus dinyatakan sebagai tindakan yang tidak berdasar hukum (unlawful), karena dianggap sebagai tindakan yang illegal.

Fungsi pengawalan konstitusi adalah untuk menjaga kesakralan dari sebuah konstitusi. Sehingga fungsi tersebut hanya dimiliki oleh satu lembaga negara yang berwenang dan independen, dalam hal ini adalah Mahkamah Konstitusi. Hal ini karena Mahkamah Konstitusi merupakan lembaga yang berfungsi untuk menafsirkan dan menjaga konstitusi. Secara prinsip kewenangan Mahkamah Konstitusi tidak hanya terbatas pada hal-hal yang termuat dalam Pasal 24C UUD 1945 maupun UU Mahkamah Konstitusi. Tetapi, secara tersirat kewenangan Mahkamah Konstitusi meliputi pengawalan terhadap konstitusi termasuk menyelesaikan perkara yang diajukan perorangan (individu) warga negara yang merasa hak-hak konstitusionalnya (constitutional rights atau basic rights) dirugikan oleh keputusan suatu institusi negara, baik legislatif, eksekutif, maupun yudikatif.

\section{B.3. Kewenangan Mengadili Constitutional Complaint}

Mahkamah Konstitusi sebagai satusatunya lembaga peradilan yang memiliki fungsi untuk mengawal konstitusi, maka sudah semestinya memiliki kewenangan untuk memutus Constitutional Complaint. Adapun ketentuan tersebut dimaksudkan untuk dapat menangani berbagai perkara atas pelanggaran hak konstitusional yang tidak ada instrumen hukum atasnya untuk memperkarakannya atau tidak tersedia lagi atasnya jalur penyelesaian hukum/peradilan). Sedangkan, subjek yang merasa dirugikan dapat diajukan perorangan (individu) warga negara yang merasa hak-hak konstitusionalnya (constitutional rights atau basic

11 Abdul Mukhti Fadjar, Konstitusionalisme Demokrasi, In-TRANS Publishing, Malang, 2010, hlm. 1

12 Richard C. Schroeder, Garis Besar Pemerintahan Amerika Serikat, (Kantor Program Informasi Internasional Departemen Luar Negeri Amerika Serikat, 2000), hlm. 96

13 M. Yahya Harahap, Beberapa Tinjauan Mengenai Sistem Peradilan dan Penyelesaian Sengketa, Citra Aditya Bhakti, Jakarta, 1997, hlm. 44 
rights) dirugikan oleh keputusan suatu institusi negara, baik legislatif, eksekutif, maupun yudikatif. Hal ini dimaksudkan bahwa hak dasar atau hak asasi yang dimiliki oleh setiap warga negara tidak bisa dikurangi atau diganggu sedikitpun, baik oleh individu, kelompok, bahkan oleh negara.

Kewenangan Mahkamah Konstitusi yang kita kenal, yakni melakukan pengujian Undang- Undang terhadap UUD 1945 (Judicial review). Pengujian tersebut hanya sebatas pada pelanggaran hak konstitusional warga negara yang diatur di dalam bentuk undang-undang. Akan tetapi, untuk memutus Constitutional Complaint, Mahkamah Konstitusi saat ini masih terkendala karena kewenangan yang diatur secara ekplisit dalam UUD 1945, dengan tegas tidak mengatur kewenangan tersebut. Meskipun demikian, mengingat pentingnya perlindungan terhadap hak-hak konstitusional warga negara, maka fungsi Mahkamah Konstitusi sebagai lembaga pengawal konstitusi dipandang perlu memiliki kewenangan Constitutional Complaint.

Mekanisme Constitutional Complaint di Indonesia belum termuat secara eksplisit di konstitusi, artinya tidak tertulis dalam UUD 1945. Namun secara tersirat terkandung adanya hak-hak konstitusional warga yang dilindungi oleh negara. Sehingga bagi setiap warga negara yang merasa hak-hak konstitusionalnya dilanggar oleh tindakan penguasa dapat mengajukan perkara kepada lembaga peradilan yang berwenang, dalam hal ini adalah Mahkamah Konstitusi (sesuai fungsinya sebagai pengawal konstitusi). Hal tersebut terkait erat dengan teori pembangunan hukum responsif, yakni teori yang menyatakan bahwa bingkai hukum pada prinsipnya harus partisipatif, serta berisi nilainilai yang tepat berdasarkan asas-asas hukum yang berkembang dalam masyarakat. ${ }^{14}$

Berdasarkan ketentuan Pasal 24 ayat (1) dan ayat (2) UUD 1945 juncto Pasal 2 UU Nomor 24 Tahun 2003 Tentang Mahkamah Konstitusi, bahwa kedudukan Mahkamah Konstitusi adalah: ${ }^{15}$

a. Merupakan salah satu lembaga negara yang melakukan kekuasaan kehakiman;

b. Merupakan kekusaan kehakiman yang merdeka; dan

c. Sebagai penegak hukum dan keadilan.
Adapuntugas danfungsi Mahkamah Konstitusi sebagaimana yang termaktub dalam Penjelasan Umum Undang-Undang No.24 Tahun 2003, bahwa menangani setiap perkara ketatanegaraan atau perkara konstitusi tertentu dalam rangka menjaga konstitusi agar dilaksanakan secara bertanggung jawab sesuai dengan kehendak rakyat dan cita-cita demokrasi. Keberadaan MK sekaligus untuk menjaga terselenggaranya pemerintahan yang stabil, dan juga merupakan koreksi pengalaman ketatanegaraan dimasa lalu yang ditimbulkan oleh tafsir ganda terhadap konstitusi. Dalam Pasal 28 UUD 1945 dinyatakan bahwa "Kemerdekaan berserikat dan berkumpul, mengeluarkan pikiran dengan lisan dan tulisan dan sebagainya ditetapkan dengan undang-undang".

Berdasarkan pasal tersebut diatas secara jelas sudah tersirat bahwa kebebasan dan hak-hak konstitusi warga negara dilindungi oleh UUD 1945, hal ini berarti bahwa negara melalui perangkatnya tidak bisa melanggar hak-hak warga tersebut. Karena hak-hak konstitusi warga negara merupakan hak dasar yang wajib untuk dillindungi oleh negara. Kewenangan dalam menyelesaikan perkara terkait pelanggaran konstitusional warga negara pada umumnya disebut kewenangan. Constitutional Complaint. Menurut Moh. Mahfud MD, ${ }^{16}$ pengertian Constitutional Complaint adalah pengajuan perkara ke Mahkamah Konstitusi atas pelanggaran hak konstitusional yang tidak ada instrumen hukum atasnya untuk memperkarakannya atau tidak tersedia lagi atasnya jalur penyelesaian hukum/peradilan.

Dalam pandangan Ahmad Syahrizal, Constitutional Complaint adalah mekanisme pengaduankonstitusionalbagisetiapwarganegara atau masyarakat yang ingin mempertanyakan dugaan pelanggaran hak konstitusional kepada peradilan konstitusi. ${ }^{17}$ Sebagai contoh negara yang sudah menerapkan Constitutional Complaint dalam sistem peradilannya adalah Jerman dan Korea, di Jerman Constitutional Complaint dikenal dengan nama verfassungsbechwerde. Setiap warga negara yang merasa hak-hak fundamentalnya dilanggar oleh pejabat publik dapat mengajukan Constitutional Complaint ke Mahkamah Konstitusi. Tetapi pengaduan ini baru bisa dilakukan apabila sudah melewati

14 Anis Ibrahim, Merekonstruksi Keilmuan Ilmu Hukum \& Hukum Milenium Ketiga, In-TRANS, Malang, 2007, hlm.7

15 Abdul Mukhti Fadjar, Hukum Konstitusi dan Mahkamah Konstitusi, Sekreteriat Jendral dan Kepaniteraan Mahkamah Konstitusi, Jakarta, 2005, hlm. 119.

16 Moh. Mahfud MD, Konstitusi dan Hukum dalam Kontroversi Isu, PT. RadjaGrafindo Persada, Jakarta, 2010, hlm. 287

17 Ahmad Syahrizal, Peradilan Konstitusi Suatu Studi tentang Adjudikasi Konstitusional Sebagai Mekanisme Penyelesaian Sengketa Normatif, PT. Pradnya Paramita, Jakrta, 2006, hlm.102 
sarana pengadilan lain. Pengajuan Constitutional Complaint tidak dikenai biaya serta dalam proses beracara pun tidak wajib untuk didampingi pengacara.

\section{Penutup}

Mahkamah Konstitusi selaku lembaga negara yang diatur dalam UUD 1945 dan UU MK secara prinsip diposisikan sebagai pengawal konstitusi (the guardian of constitution), penafsir akhir konstitusi (the final interpreter of constitution), pengawal demokrasi (the guardian of democracy), pelindung hak-hak konstitusional warga negara (the protector of citizen's constitutional rights), dan pelindung hak-hak asasi manusia (the protector of human rights). Sehingga, sebagai lembaga yang berfungsi untuk mengawal konstitusi, maka Mahkamah Konstitusi dalam konteks perlindungan sekaligus penegakan hukum harus memiliki kewenangan untuk menyelesaikan Constitutional Complaint, dengan tujuan untuk melindungi hak-hak warga negara yang telah dirugikan hak konstitusionalnya. Oleh karenanya, dapat dirumuskan bahwa sesungguhnya kewenangan terkait dengan Constitutional Complaint ini adalah merupakan bagian dari perluasan dan penguatan terhadap kewenangan Mahkamah Konstitusi.

\section{Daftar Pustaka}

Asshiddiqie. Jimly, Konstitusi dan Konstitusionalisme Indonesia, Edisi Revisi, Jakarta: Konstitusi Press, 2005.

Menuju Negara Hukum Yang Demokratis, (Jakarta: PT.Bhuana Ilmu Populer,2009.

Utrecht, Pengantar Hukum Administrasi Negara Indonesia, Jakarta:Ichtiar, 1962.
Fadjar. Abdul Mukhti, Hukum Konstitusi dan Mahkamah Konstitusi, Jakarta, Sekreteriat Jendral dan Kepaniteraan Mahkamah Konstitusi, 2005.

Konstitusionalisme Demokrasi, Malang : In-TRANS Publishing, 2010.

Harahap. M. Yahya, Beberapa Tinjauan Mengenai Sistem Peradilan dan Penyelesaian Sengketa, Jakarta: Citra Aditya Bhakti, 1997.

Ibrahim. Anis, Merekonstruksi Keilmuan Ilmu Hukum \& Hukum Milenium Ketiga, Malang: In-TRANS, 2007.

MD. Moh. Mahfud, Konstitusi dan Hukum dalam Kontroversi Isu, Jakarta: PT. RadjaGrafindo Persada, 2010.

Richard C. Schroeder, Garis Besar Pemerintahan Amerika Serikat, Kantor Program Informasi Internasional Departemen Luar Negeri Amerika Serikat, 2000.

Ahmad Syahrizal, Peradilan Konstitusi Suatu Studi tentang Adjudikasi Konstitusional Sebagai Mekanisme Penyelesaian Sengketa Normatif, Jakarta : PT. Pradnya Paramita, 2006.

Jimly Asshiddiqie, Negara Hukum Indonesia, Makalah, dalam rangka Pelantikan Dewan Pimpinan Pusat Ikatan Alumni Universitas Jayabaya, di Jakarta, 2010.

Jurnal Hukum Jentera, Komisi Negara, Jakarta: PSHK, Edisi 12-Tahun III, 2006.

Undang-Undang Dasar Negara Republik Indonesia Tahun 1945

Undang-Undang No.24 Tahun 2003 Tentang Mahkamah Konstitusi. LN No. 98 Tahun 2003, TLN No. 4316. 